Int. J. Odontostomat.,

12(4):343-347, 2018.

\title{
Arterial Embolization in the Treatment of Severe Epistaxis: A Case Report
}

\author{
Embolización Arterial en el Tratamiento de la Epistaxis Severa: Reporte de un Caso
}

\author{
Ferdinando de Conto'; Simone Siqueira²; Jaqueline Colaço²; \\ Leonardo Tonietto3; Rafael D’Agostini Annes ${ }^{5}$ \& José Ricardo Vanzin 5
}

CONTO, F.; SIQUEIRA, S.; COLAÇO, J.; TONIETTO, L.; ANNES, R. D. \& VANZIN, J. R. Arterial embolization in the treatment of severe epistaxis: A case report. Int. J.Odontostomat., 12(4):343-347, 2018.

ABSTRACT: Nasal hemorrhage or epistaxis is a common finding in the emergency department. The causes of epistaxis are varied and can be classified as local, systemic or a combination of both. The aim of this study was to report a case of embolization of branches of the maxillary artery for treatment of epistaxis secondary to facial trauma. A 43-year-old man suffered blunt trauma in the frontonasal area as a result of a bicycle accident. It presented with amnesia, severe epistaxis, panfacial edema and nasal deformity. The patient was hypotensive and hypothermic, with evidence of hemorrhagic intracranial. Orotracheal intubation was performed immediately to protect the airways and prevent aspiration of blood to the lower respiratory tract. The occlusion of the artery was successful and was immediately followed by cessation of oronasal bleeding. The patient was discharged after ten days. Arterial embolization should be the gold-standard treatment, which provides a safe and effective alternative for the control of epistaxis.

KEY WORDS: diagnosis, traumatology, bleeding.

\section{INTRODUCTION}

Nosebleed, or epistaxis, is a common finding in the emergency department. Approximately $60 \%$ of the population will experience at least one episode of epistaxis during their lives, with only $6 \%$ of such episodes requiring specialized care (Beck et al., 2018). More severe cases of epistaxis can lead to hemodynamic instability, jeopardize airway patency, and cause cerebral hypoperfusion (Wu et al., 2007). Rapid and effective management of these episodes is essential to keep morbidity and mortality to a minimum (Fig. 1).

The causes of epistaxis are varied, and can be classified as local (anatomical defects in the nasal septum, trauma, surgical complications, vascular malformations, neoplasms), systemic (hypertension, use of nonsteroidal anti-inflammatory drugs, hereditary hemorrhagic telangiectasia, disorders of hemostasis), or a combination thereof (Strach et al., 2011).
Facial trauma often causes some degree of nasal bleeding. Therefore, oral and maxillofacial surgeons and trauma specialists must be familiarized with the anatomy, diagnosis and management of epistaxis and its systemic complications (Yas, 2015).

Epistaxis usually resolves spontaneously or is amenable to local measures, such as manual compression, topical vasoconstrictors, electrocautery, and anterior and/or posterior nasal packing. More severe cases may be unresponsive to these local measures; in these cases, invasive procedures such as vessel ligation, endoscopic surgery, and arterial embolization may be indicated (Strach et al.; de Bonnecaze et al., 2017).

We report a case of embolization of maxillary artery branches for treatment of epistaxis secondary to facial trauma. A review of the literature highlights

\footnotetext{
${ }^{1}$ Surgery and Traumatology Residence Service Bucomaxillofacial of the University of Passo Fundo (UPF) and Hospital of the City of Passo Fundo - RS, Brazil.

${ }^{2}$ Dentist Surgery University of Passo Fundo - RS, Brazil.

${ }^{3}$ Bucomaxillofacial Surgery and Traumatology Service Bom Pastor Hospital, Igrejinha - RS, Brazil.

${ }^{4}$ Neurosurgery Department, Hospital da Cidade, Passo Fundo, Brazil.

${ }^{5}$ Residence of neurosurgery service Hospital City Passo Fundo - RS, Brazil.
} 


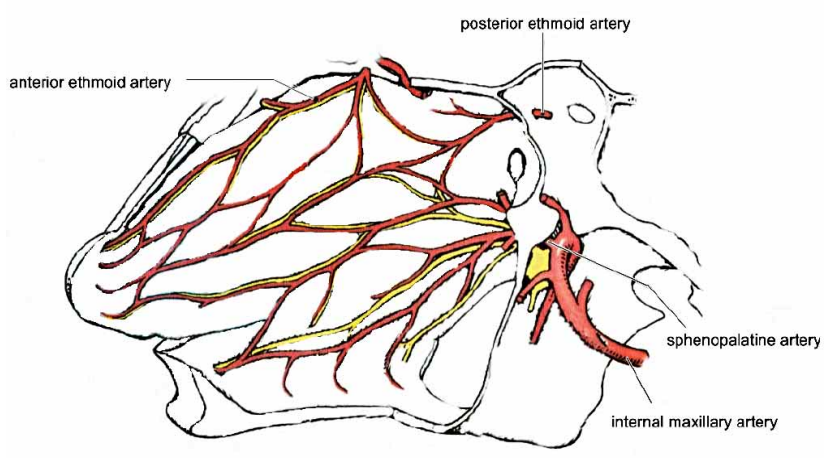

Fig. 1. Vascular anatomy of the nasal region.

the importance of establishing a protocol for management of epistaxis, which is still an underrepresented topic in oral and maxillofacial surgery and trauma surgery journals.

Anatomical considerations. The most common site of epistaxis is the anterior septal region, also known as Kiesselbach's plexus or Little's area4. Bleeding originating in this area of the anterior nares usually resolves spontaneously or can be controlled with conservative local measures. The nasal cavity is irrigated by the internal carotid artery (ICA), which gives off the ophthalmic artery and its branches, the anterior and posterior ethmoid arteries, and the external carotid artery (ECA), via the internal maxillary artery and its sphenopalatine and descending palatine branches (Strach et al.; Yas). The anterior-most aspect of the nasal septum contains small ramifications of the superior labial artery, which is itself a branch of the facial artery.

The blood supply of the posterior septal region originates from the sphenopalatine and descending palatine arteries, which, as mentioned above, are branches of the maxillary artery. The posterior ethmoid artery often provides a minor contribution to the irrigation of this area (Yas).

Severe bleeding originating in the ethmoid arteries usually can only be controlled by surgical means, through a modified Lynch procedure and ligation of the anterior ethmoid artery (a branch of the ICA) (Yas).

The main vessel leading into the nasal cavity is the sphenopalatine artery, which irrigates both the nasal septum and the lateral wall of the cavity (Noy et al., 2017). Severe epistaxis nearly always originates from the sphenopalatine artery, usually from its septal portion and, less commonly, from its posterior lateral portion (Djindjian et al., 1973).

\section{CASE REPORT}

A 43-year-old male sustained direct blunt trauma to the frontonasal area as the result of a bicycle accident. He was brought to the Emergency Department of Hospital da Cidade de Passo Fundo, Rio Grande do Sul, Brazil, with amnesia, severe epistaxis, panfacial edema, and nasal deformity. On admission, the patient underwent routine trauma assessment, including a neurological and oral/ maxillofacial examination, which revealed no abnormalities beyond the aforementioned craniofacial injuries. Due to copious, simultaneous bleeding from the anterior nares and oral cavity, posterior nasal packing was performed with the aid of a 16F Foley catheter, despite full knowledge of the risk of cerebral penetration through a fractured cribriform plate. Bilateral anterior nasal packing with ribbon gauze was also performed.

The patient underwent a period of 18 hours for observation, but persisted bleeding, he was hypotensive and hypothermic, providing further evidence of the severity of his condition. Orotracheal intubation was performed immediately to secure the airway and prevent aspiration of blood into the lower respiratory tract, and two units of packed red blood cells were transfused to maintain hemodynamic stability. A computed tomography scan of the head and face showed multiple frontal, nasal, orbital, and ethmoid fractures, as well as blood in all paranasal sinuses (Fig. 2). There was, however, no evidence of intracranial hemorrhage. Repeat examination over the 24 hours following nasal packing revealed persistent active bleeding despite a substantial reduction in blood loss. The patient was transferred to the interventional radiology department for cerebral angiography, which revealed an area of contrast blush suggestive of bleeding from a branch of the right maxillary artery.

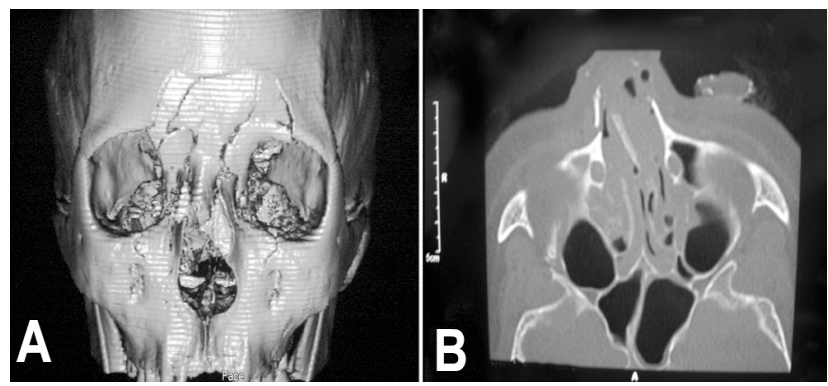

Fig. 2. Computed tomography of the head and face. A) Threedimensional reconstruction showing panfacial (frontal/nasal/ orbital/ethmoid) fractures. B) Axial image showing blood-filled paranasal sinuses. 
The sphenopalatine branches of the right maxillary artery were embolized with 300-500 mm polyvinyl alcohol (PVA) particles (Fig. 3). Occlusion of the artery was successful and was immediately followed by cessation of oronasal bleeding. Within a few days, the patient was deemed hemodynamically stable and underwent surgical correction of his panfacial fractures. He was discharged 10 days after admission.
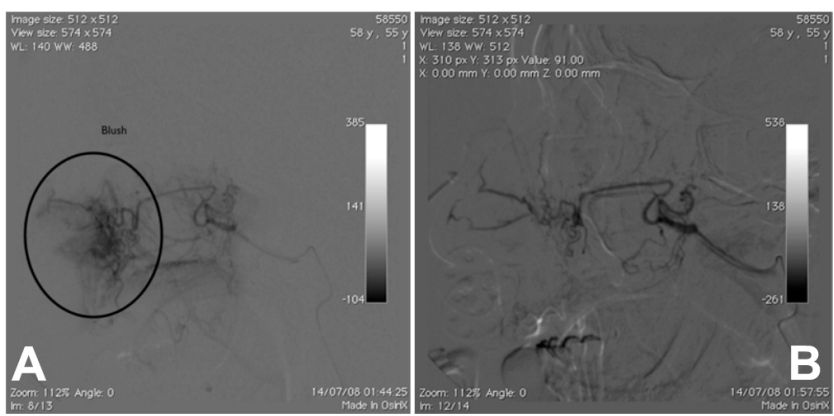

Fig. 3. Fluoroscopic view: A) Lateral view during superselective catheterization of the right maxillary artery. Contrast blush is visible in the nasal mucosa irrigated by the sphenopalatine artery, confirming active bleeding. B) Lateral view showing successful hemostasis after embolization with 300-500 mm PVA particles, with no evidence of active bleeding.

\section{DISCUSSION}

The initial approach to the patient presenting with vigorous epistaxis associated with facial trauma should follow Advanced Trauma Life Support (ATLS) protocols. Maintenance of airway patency, ventilatory control, and hemostasis of bleeding injuries are part of routine trauma care (Cogbill et al., 2008).

Severe nasal bleeding secondary to facial trauma is not common. However, when it does occur, it is often life-threatening due to airway compromise and hypovolemia (Wu et al.; de Bonnecaze et al.).

Orotracheal intubation is the mainstay of airway management in patients with nasal hemorrhage. The nasotracheal route should be avoided. If tissue injury, edema, or bleeding precludes oral intubation, a surgical airway technique (cricothyroidotomy or emergency tracheostomy) should be used instead (Cogbill et al.). In the case reported herein, orotracheal intubation was successful.

Many authors have suggested stepwise treatment protocols for the management of epistaxis.
Local measures should be attempted initially. Visible bleeders can be compressed, cauterized, or ligated when possible; anterior and posterior nasal packing are the most widely used local measures, and can be effective for moderate epistaxis (Cogbill et al.). Packing is often used as a first-line measure even in more severe bleeding, as it can facilitate airway maintenance and minimize blood loss while more serious injuries or hemorrhage elsewhere in the body-such as in the chest cavity or abdomen-are assessed. Once other severe injuries have been ruled out, treatment should focus on control of epistaxis.

If local measures are insufficient for hemostasis and the patient begins to develop hemodynamic instability, which can lead to shock, invasive measures must be considered. Several studies have proposed criteria to guide this decision-making process. Chen et al. (2009) proposed that, if systolic blood pressure falls below $\leq 90 \mathrm{mmHg}$ or fluid replacement in excess of $1500 \mathrm{~mL}$ is required, arterial embolization should be considered immediately. However, most authors consider failure of conservative treatment or instability of vital signs as the trigger for invasive interventions such as vessel ligation or angioembolization (Wu et al.; Cogbill et al.; Noy et al.). In the case reported herein, instability of vital signs and persistent bleeding despite anterior and posterior nasal packing justified invasive intervention arterial embolization.

Oronasal hemorrhage from venous origin or minor arterial vessels due to maxillofacial trauma can often be managed efficiently with packing, however, if bleeding persists and represent risk for the patient's life, vessels ligation and arterial embolization are treatment options (Wu et al.).

External carotid artery ligation rarely proves effective for control of nasal hemorrhage, due to the extensive contralateral vasculature (Cogbill et al.; de Bonnecaze et al.; Debelmas et al., 2017). Furthermore, the complications associated with ECA ligation are substantial and the procedure requires general anesthesia, which poses additional risk and increases morbidity and mortality in hemodynamically unstable patients. The ligation of the external carotid, is a complicated surgery and can damage the vagus and hypoglossal nerves, and other structures (de Bonnecaze et al.).

The options available for invasive treatment of severe epistaxis are vessel ligation (of the external carotid artery or maxillary artery) and arterial 
embolization. The Emergency Department staff of Hospital da Cidade de Passo Fundo, prefer use arterial embolization as a treatment option, as currently offers huge benefit in the management of epistaxis (Reyre et al., 2015).

Arterial embolization provides several advantages over vessel ligation. Surgical exploration of complex wounds, with attendant edema, soft tissue defects and comminuted fractures, can be extremely challenging. Microcatheter angiography can be performed at sites remote from the actively bleeding lesion and different sources of bleeding - often bilateral-can be identified by fluoroscopy (as extravasation of contrast media from the affected artery) and controlled by embolization, a procedure that can be performed relatively quickly and under local anesthesia (Chen et al.; Yas). Angiography can also identify bleeding originating from the ethmoid arteries, branches of the ophthalmic artery, an event that requires direct surgical access and vessel ligation for hemostasis (Debelmas et al.). Furthermore, preembolization angiography can provide valuable information on vascular abnormalities and the extent of the site of bleeding (Strach et al.; Beck et al.).

Strach et al. note that arterial embolization is a quick procedure and can easily be repeated as necessary; furthermore, early endovascular intervention can shorten length of stay and minimize transfusion requirements. Wu et al. state that early arterial embolization minimizes hypoperfusion, thus preventing further neurologic damage.

The occlusive agents used in arterial embolization are polyvinyl alcohol particles, gelatin sponge, butyl-cyanoacrylate, metal coils, and concentrated alcohol (Yas).

Several authors have reported high success rates $(87.5-96 \%)$ with arterial embolization for control of epistaxis, with a low rate of complications (1.9-21 $\%$ ), which, nevertheless, have included tissue necrosis, blindness, facial nerve palsy, and migration of the embolus to the ICA and vertebral arteries (Djindjian et al.; Wu et al.; Cogbill et al.; de Bonnecaze et al.).

\section{CONCLUSION}

In the management of epistaxis, there are several forms of treatment for, conservative measures should always precede more invasive interventions. When nonsurgical measures fail, arterial embolization should be the treatment of choice, as it provides a safe and effective alternative for control of severe epistaxis.

CONTO, F.; SIQUEIRA, S.; COLAÇO, J.; TONIETTO, L.; ANNES, R. D. \& VANZIN, J. R. Embolización arterial en el tratamiento de la epistaxis severa: Reporte de un caso. Int. J. Odontostomat., 12(4):343-347, 2018.

RESUMEN: La hemorragia nasal o epistaxis es un hallazgo común en el servicio de urgencias. Las causas de la epistaxis son variadas y pueden clasificarse como locales, sistémicas o una combinación. El objetivo de este estudio fuerelatar un caso de embolización de ramas de la arteria maxilar para el tratamiento de epistaxis secundaria a trauma facial. Um hombre de 43 años de edad sufrió traumatismo contuso en la zona frontonasal como consecuencia de un accidente de bicicleta. Se presentaba con amnesia, epistaxis grave, edema panfacial y deformidad nasal. El paciente fue hipotenso y hipotermático, con evidencia de hemorragia intracraneal. La intubación orotraqueal fue realizada inmediatamente para proteger las vías aéreas y evitar la aspiración de sangre para el tracto respiratorio inferior. La oclusión de la arteria fue exitosa y fue seguida inmediatamente por cesación de sangramiento oronasal. El paciente fue dado de alta después de diez días. La embolización arterial debe ser el tratamiento de elección, que proporciona una alternativa segura y eficaz para el control de la epistaxis.

PALABRAS CLAVE: diagnóstico, traumatología, sangramiento.

\section{REFERENCES}

Beck, R.; Sorge, M.; Schneider, A. \& Dietz, A. Current approaches to epistaxis treatment in primary and secondary care. Dtsch. Arztebl. Int., 115(1-2):12-22, 2018.

Chen, Y. F.; Tzeng, I. H.; Li, Y. H.; Lo, Y. C.; Lin, W. C.; Chiang, H. J.; Chen, R. F. \& Shen, W. C. Transcatheter arterial embolization in the treatment of maxillofacial trauma induced life-threatening hemorrhages. J. Trauma, 66(5):1425-30, 2009.

Cogbill, T. H.; Cothren, C. C.; Ahearn, M. K.; Cullinane, D. C.; Kaups, K. L.; Scalea, T. M.; Maggio, L.; Brasel, K. J.; Harrison, P. B.; Patel, N. Y.; Moore, E. E.; Jurkovich, G. J. \& Ross, S. E. Management of maxillofacial injuries with severe oronasal hemorrhage: a multicenter perspective. J. Trauma, 65(5):994-9, 2008.

de Bonnecaze, G.; Gallois, Y.; Chaynes, P.; Bonneville, F.; DupretBories, A.; Chantalat, E. \& Serrano, E. Intractable epistaxis: which arteries are responsible? An angiographic study. Surg. Radiol. Anat., 39(11):1203-7, 2017.

Debelmas, A.; Lanciaux, S. \& Schouman, T. A case of epistaxis. J. Stomatol. Oral Maxillofac. Surg., 118(6):383-4, 2017.

Djindjian, R.; Merland, J. J.; Rey, A.; Thurel, J. \& Houdart, R. Superselective arteriography of the external carotid artery. Importance of this new technic in neurological diagnosis and in embolization. Neurochirurgie, 165-71, 1973. 
Noy, D.; Rachmiel, A.; Emodi, O.; Amsalem, Y.; Israel, Y. \& Nagler, R. M. Transarterial embolization in maxillofacial intractable potentially life-threatening hemorrhage. J. Oral Maxillofac. Surg., 75(6):1223-31, 2017.

Reyre, A.; Michel, J.; Santini, L.; Dessi, P.; Vidal, V.; Bartoli, J. M.; Moulin, G. \& Varoquaux, A. Epistaxis: The role of arterial embolization. Diagn. Interv. Imaging, 96(7-8):757-73, 2015.

Strach, K.; Schröck, A.; Wilhelm, K.; Greschus, S.; Tschampa, H.; Möhlenbruch, M.; Naehle, C. P.; Jakob, M.; Gerstner, A. O.; Bootz, F.; Schild, H. H. \& Urbach, H. Endovascular treatment of epistaxis: indications, management, and outcome. Cardiovasc. Intervent. Radiol., 34(6):1190-8, 2011.

Wu, S. C.; Chen, R. J.; Lee, K. W.; Tung, C. C.; Lin, W. P. \& Yi, P. Angioembolization as an effective alternative for hemostasis in intractable life-threatening maxillofacial trauma hemorrhage: case study. Am. J. Emerg. Med., 25(8):988.e1-5, 2007.

Yas, S. An update on epistaxis. Aust. Fam. Physician, 44(9):653-6, 2015.
Corresponding author:

Ferdinando de Conto

Universidade de Passo Fundo

BR 285, Bairro São José

99052-900, Passo Fundo - RS

BRAZIL

E-mail: 122981@upf.br

Received: 13-04-2018

Accepted: 08-10-2018 